\title{
Review on the Prices of Shipment Keep Rising in Perspective of Global Shipping Supply Chain Disruption
}

\author{
Yu Luan \\ School of Law, Shanghai Maritime University, Shanghai 201306, China
}

\begin{abstract}
The global spread of the pandemic has led to the stop of various industries, the shutdown of enterprises, the unemployment of workers and other problems. Recently, one of the issues that have aroused widespread global concern is the problem that the international shipping prices represented by the trans Pacific route continuously rising. This is the apparent performance of the global shipping supply chain interruption and brings interruption to the global supply chain. International shipping is a barometer of the international economic. The reasons behind the sharp rise in shipping prices are complex and diverse. The labor shortage under the pandemic is the root cause of low operation efficiency. The serious shortage of export containers in Asia is the direct cause of demand exceeds supply. The imbalance of international trade is the internal reason for the increase in demand. In addition, there are additional reasons such as the congestion accident in Suez Canal. In order to deal with this situation, each governments use policies, decrees and other measures to intervene moderately on the basis of the market power to restore balance for hoping to recover as soon as possible. But some international organizations related to this issue hold the opposite attitude. Shipping operators have interests directly relevant should reasonably dispatch all available transport capacity to meet demand, rationally treat and make use of short-term high profits and actively cooperate in the face of national survey, review and supervision. The problem of global shipping supply chain interruption needs to be solved jointly by all parties and strengthen pandemic control then solve the problem from the source, to release the delayed transportation efficiency as soon as possible to restore the global shipping supply chain and promote the recovery of the world economy.
\end{abstract}

Keywords: Global Shipping Supply Chain Disruption; Shipping Prices Keep Rising; Labor Shortage; Container Shortage; Global Trade Imbalances; Supply Chain Interruption Management.

\section{Introduction}

\subsection{Price Sharp Increase Triggered by Container Crisis}

At present, faced with the profound changes in the global economy, the global supply chain and trade pattern are undergoing profound adjustment brought by the interruption of global logistics, especially shipping supply chain. The supply chain interruption triggered by the global pandemic ignited a global shipping crisis which was mainly reflected in the soaring freight rates caused by the shortage of available containers. Since the third quarter of 2020, the phenomenon of lack of containers and less containers have occurred in major ports one after another. The report on China Shipping Prosperity Index in the fourth quarter of 2020 released by Shanghai International Shipping Institute points out that more than 90 per cent of container transportation enterprises say that the problem of container shortage will last for three months or more, of which 25 per cent of container transportation enterprises say that the problem of container shortage will last for half a year or more. 2021 has entered the second half of the year, however, this problem has not been solved or even greatly alleviated. Otherwise, when China suffered available export empty containers crisis Auckland port in New Zealand has a backlog of nearly 6000 empty containers that cannot be transported away, 10000 to 15000 containers are stranded in California of the United States and the number of empty containers in Australian ports is also more than 50000.The root cause is that the core of this problem lies in the imbalance of global trade amplified by the global pandemic. Therefore, the shortage of containers and the crazy growth of freight rates are predicted could be continuous.

Since the shipping containers crisis happened, the combined effect of various pressures has escalated the shipping cost to more than four times the normal level. At the end of 2020, according 
to different routes, the prices of shipment of most shipping companies have increased by 2-10 times. According to the Financial Times, the price of a 40-foot container routed from Asia to Northern Europe has risen from US \$2000 to US \$9000. Meanwhile, the Consumer News and Business Channel (CNBC) reported that the cost of transporting goods from Asia to the west coast of the United States increased by 145 per cent. The anxiety of enterprises continues to push up the price of container transportation. Moreover, with the arrival of the traditional shipping season shipping companies generally raise surcharges. The usual price of 20-foot containers from Asia to the United States is $\$ 800-900$ per container but now it has risen to $\$ 3300$, while the price to Germany has risen to $\$ 6000$ per container. Even at such a high price, there is hard to seek available empty container.

\subsection{The Interruption of Global Shipping Supply Chain Directly Results in the Interruption of Global Supply Chain}

The interruption of a link of the global supply chain will be transmitted to the global market through a huge and complex supply chain network and trigger a chain reaction between upstream and downstream. Shipping supply chain has so as an important part of global supply chain. More than 90 per cent of international trade transportation is completed by sea. Therefore, the consequences of the interruption of the global shipping supply chain are always serious and the delay of shipping schedule is the most obvious. Delayed delivery may cause damage or loss of cargoes and face claims as well as additional expenses such as time and fuel costs. On the other hand, it has an impact on the market and economy. The interruption of the supply chain may cause enterprises to stop production due to the shortage of raw materials, moreover, the shortage of market commodities with stagnant commodity transportation could result in rising prices which will cause losses to global trade and the subsequent world economy.

Shipping supply chain disruption affects the world economic cycle, not only the international cycle but also China's domestic cycle. Therefore, China should attach great importance to global supply chain security and take measures to accelerate the recovery and improve the risk management of supply chain disruption. Due to the above reasons, the import and export are hindered, the enterprises cannot get available empty containers, the goods are retained in the warehouse or stay in the port for packing which all will incur expenses and affect the quality of the goods. The manufacturer may not have a clear shipping date and schedule for half a year.

\section{The Causes of the Continuous and Substantial Increase of Shipping Prices as Direct Reflection of Interruption of Global Shipping Supply Chain}

\subsection{Labor Shortage is the Root Cause}

In order to prevent the spread of the pandemic, the working and production stop protect against crowds gathered in the workplace directly cause the labor shortage of various industries. The extent of labor shortage is closely related to the situation of pandemic control. The pandemic control situation is different from state to state, so the extent of labor shortage is also different. The pandemic control in China has achieved remarkable results and labors returned to work and production quickly. It forms a big difference from the production stagnation caused by the ineffective control or frequently repeated pandemic in the United States, Europe and other similar countries and regions. It is the root cause of global trade imbalance, global shipping imbalance, especially container import and export and global supply chain interruption.

The shipping industry could be called a labor-intensive industry with a large number of types of work requiring labor, especially in the port loading and unloading links at both ends of the transportation requiring a large number of labors not only in warehouses, storage yards and domestic transshipment. The shortage of labor force significantly reduces the operation efficiency of ports, warehouses, storage yards, inland transportation and other links further resulted in the reduction of the efficiency of the whole supply chain. The shortage of truck drivers leads to the speed of picking 
up and returning containers slow down obviously which affects the circulation efficiency of containers. The decline in the capacity of logistics system, ports congestion and extensive period of cargo inspection, the cargo backlog and schedule of global shipping companies are delayed also make the container circulation speed down and the shortage of containers in Asia.

Another aspect of labor shortage is the shortage of crew. The shortage of crew and the difficulty of changing shifts have been exacerbated by the aggravation of the pandemic in India. In addition to the spread on board caused by infected crew members, Singapore and the United Arab Emirates ports prohibit ships from replacing crew members who have recently come from India and Zhoushan port in China also prohibits any ships and crew members who have visited India and Bangladesh from entering. 240 thousand seamen of 1.6 million crews in the world come from India, if this 15 per cent crew of the world cannot work normally it will also lead to a serious crew shortage and wage surge. Certainly, this aspect has little impact, even though, it is also lured to freight rate increase.

\subsection{Container Crisis is the Direct Cause}

Port congestion can be said to be the direct reason for the poor circulation and shortage of containers. A survey conducted by the International Association of Ports and Harbors (IAPH) including responses from 73 ports around the world shows that the delay of inland ports is on the rise again at the end of 2020.In addition to the major ports on the east and west of the United States, the congestion problem of major basic ports in Europe is also very serious. The punctuality rate has decreased from more than 70 per cent in normal and in common to about 20 per cent recently. The congestion of Rotterdam and Hamburg, the top two container ports in Europe, even forced shipping companies to change their shipping routes, suspend berthing or port hopping. AE7/Condor Loop 4 line of Maersk (MSK) and Mediterranean Shipping Company (MSC)will also be extended for another four weeks to omit Hamburg Port and change to unload at Bremerhaven port and Wilhelmshaven port, also inform the shipper that this has constituted "termination of transportation" according to the terms of the bill of lading. This virtually increases the shippers' transportation costs and makes it forced to find another service provider to provide transportation services from Bremerhaven port and Wilhelmshaven port to the final destination. According to Seaexplorer, the container transportation platform of Kuehne + Nagel, as of July 13, 325 vessels of major carriers had anchored and waited for berths outside ports around the world. The number of queuing ships was as high as 350, and 101 ports reported congestion and other interruptions (Figure 1). Ports congestion in mentioned places like the United States and Europe makes it impossible for containers to be unloaded and enter the following circulation parts and procedures in time so that the empty containers cannot be returned to Asia in time. Consequently, it appears a serious shortage crisis of containers in Asia especially in China.

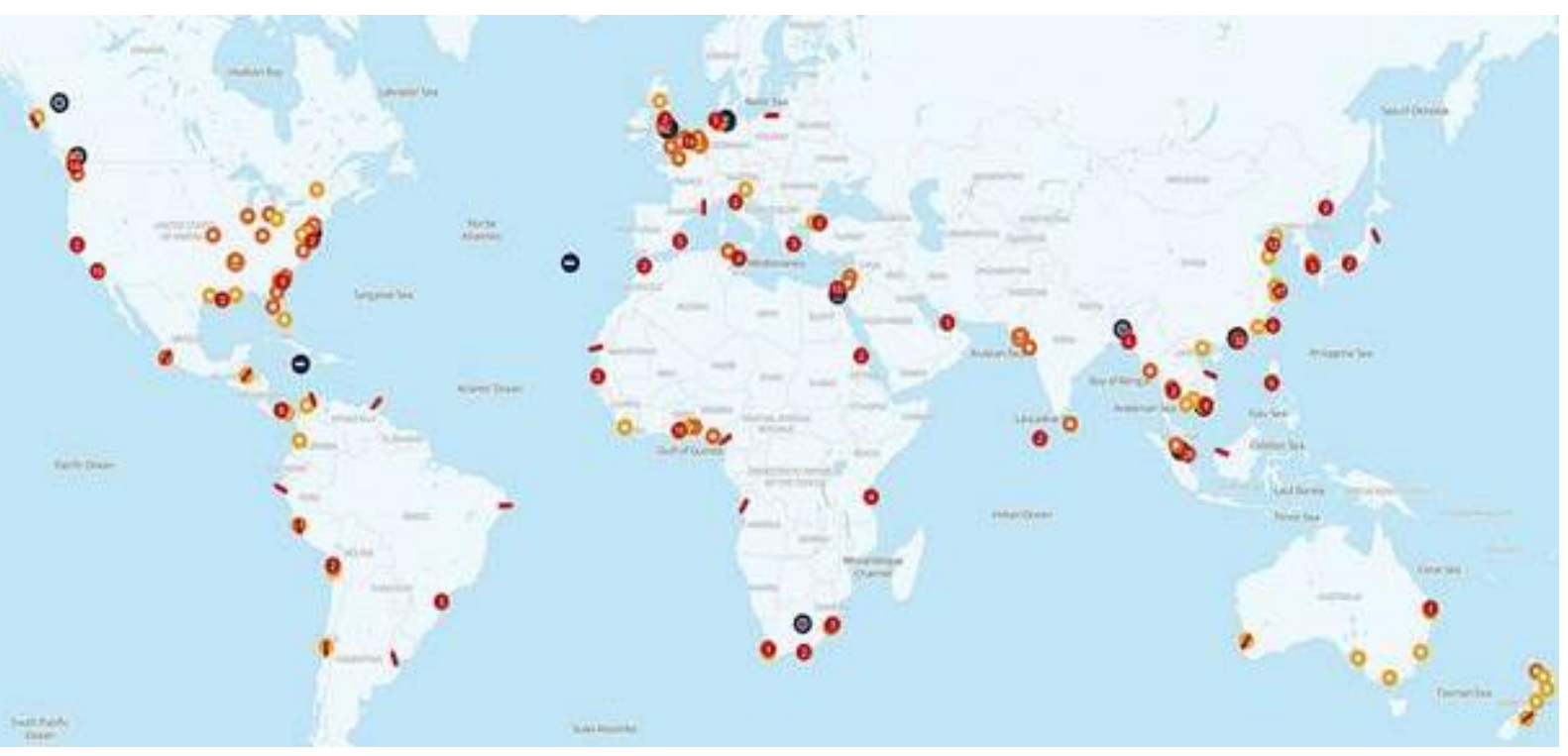

Fig 1. Global port congestion (July 13, 2021) 
In addition, stricter inspection and quarantine by customs may also cause accumulation and congestion. Because the virus may spread with imported goods such as frozen goods, for example, many places in China have reported the positive results of the nucleic acid test of the outer packaging of imported goods. Therefore, the customs will be stricter in the quarantine of imported goods than in the non-pandemic period and it also needs more processes and time. It also needs disinfection from inner to outer after the container used which also prolongs the container circulation cycle.

This means that operators in China does not have enough available containers to meet demand. In the past, it only took one to two days for ocean shipping vessels to load goods in China's ports but six to seven days under the impact of the pandemic. Therefore, China is paying a premium for importers from other countries to return containers which makes it more profitable to transport empty containers than to re-trade with those containers.

\subsection{Imbalance in Global Trade is the Internal Reason}

Since July 2020, the demand for certain commodities has prompted the supply chains of countries such as the United States and Europe to import more commodities and raw materials from China to meet consumer demand such as medical equipment, home office supplies and computer equipment, etc. With China's recovery from the cessation of trade to rebound, the volume of containers for export is about three times that of containers for import, as a result, it appears imbalance.

China's manufacturing industry drives the demand for shipping. The increase volume in export orders of production firms is the internal reason for the increase in the demand for containers or shipping spaces. The total import and export value of China's trade in goods of first half of 2021 was 18065.06 billion yuan with an increase of 27.1 per cent over the same period in 2020 and 22.8 per cent over the same period in 2019. China took the lead in restoring positive economic growth with the strong driving force among the world's major economies which shows the strong resilience of China's economy and China's important position in the global supply chain.

\section{Response of All Subjects Directly Affected by the Interruption of Global Shipping Supply Chain}

\subsection{Response of Nations}

\subsubsection{Response of China's Government}

China's government adopts the combination measures of market power and macro-control to deal with relevant problems. In order to maintain social and economic stability during the pandemic and to promote economic recovery and enterprises' resumption of work and production after the pandemic, the state has implemented many policies benefiting the people. The government uses public expenditure methods such as postpone and reduction or exemption of social security payments to help enterprises tide over financial difficulties. In order to effectively reduce the burden on shipping enterprises and ensure the normal operation of enterprises, the state has cancelled many surcharges, especially during the pandemic period, vigorously reduced or exempted port construction fees and other port fees, supported container manufacturing enterprises to expand production capacity, strengthened market supervision, tried to stabilize market prices and provide support for the stable development of trade.

As a Chinese state-owned enterprise, COSCO will also give a relatively low long-term agreement contract price under the current shipping market. For example, the price of each 20-foot standard container shipped to the east coast of the United States is US \$4000-5000 while the market price is already US $\$ 13000$.

\subsubsection{Response of Other Countries in the World}

Compared with the response scheme of Chinese government, there are mainly two solutions applied in other countries in the world. The first is similar to that of China and the second is to oppose excessive government public sector intervention in the market and rely on the business solutions. 
Due to the shortage of containers and vessels, Vietnam Maritime Administration (VMA) has received many complaints about the prices of shipment rising as its result. VMA recently sent letters to the container carriers, asked them to publicly publish the freight rate and surcharge details and warned that the VMA would not support profiteering or unreasonable freight rate which would cause difficulties for exporters and disrupt the shipping market. If so, they will be severely punished. The Fair Trade Commission Republic of Korea (KFTC) decided to conduct an anti-monopoly survey on Hyundai Merchant Marine (HMM), Heung-A Shipping and other liner shipping companies. "In order to maintain market order, any reported unfair breach of contract or unilateral change of contract terms will be subject to strict review and necessary punishment. ", The Ministry of Oceans and Fisheries of Korea contacted nine shipping companies to conduct the anti-monopoly survey. The United States recently issued a broad Executive Order to deal with related issues. The EU competition authority initially did not intend to intervene in the rise of freight rates because it believed that freight rates did not rise too much and the prices rising largely represented the fact that shipping companies were better at making money. From the above examples, it can be found that national government departments mostly adopt response measures similar to those in China and will intervene appropriately to maintain market order.

However, the view of international organizations is often the second case. For example, James Hookham who is Secretary General of the Global Shippers Forum said in his comments that shippers did not support state control of freight rates or state intervention. Any government intervention may distort the market. The World Shipping Council (WSC) believes that the Herfindahl-Hirschman Index (HHI) of the United States is currently less than 1000 and means the shipping industry is fully competitive, so carriers should continue to maintain competition and the lack of competition will lead to cargo congestion.

\subsection{Response of Shipping Service Providers}

\subsubsection{Market All Available Transport Capacity to Meet the Demand}

According to the data released by Alphaliner, as of July 10, 2021, there were 6225 container vessels in operation worldwide, with a total transport capacity of 24.8082 million TEU, equivalent to about 298 million dead weight tonnage. All of them have been put into operation except those under repair. From June 2020, more than 2.2 million TEU idle transport capacity has resumed operation and the idle capacity has decreased from 11.6 per cent in May 2020 to 1 per cent in December. New vessels with more than 600 thousand TEU will be delivered and it is estimated that more than 1.1 million TEU will be delivered in 2021 to increase the effective supply of transport capacity in market.

Globally, the output of the whole container industry in 2020 was 2.71 million TEU, an increase of 12 per cent over the previous year while the first half of the year was a year-on-year decrease of 40 per cent. The growth came from the excellent capacity of production in the second half of the year to reach 1.82 million TEU, a year-on-year increase of 93 per cent. The output in December was 440 thousand TEU and reach a record high in a single month. More transport capacity is being put into trans Pacific routes which is about four times larger than that of Asia-Europe routes.

\subsubsection{Rational Treatment and Utilization of High Revenue}

The imbalance of global trade, the pandemic situation and the difference of resumption of work and production make the demand in the international maritime transport market far greater than the supply and it is naturally reflected in the sharp rise of prices of shipment through the market force. From February to March 2021, major carriers released their financial reports for 2020 one after another. From the operating revenue in 2020 , it can be seen that the pandemic brought not the great depression predicted by all parties at the beginning of the outbreak but the general growth. (Table 1)

In 2020, the operating revenue of CMA CGM maritime segment was US \$24.23 billion, a yearon-year increase of 4 per cent. The operating revenue of Yang Ming in December 2020 was NT $\$ 16.867$ billion, about US $\$ 600$ million, a significant increase of 35.19 per cent over December 2019.The monthly profit exceeds the sum of the past ten years. Yang Ming will realize full route 
profit in 2020 which is the first time and will turn losses into profits throughout the year. According to the revenue situation of the fourth quarter of 2020 announced by Ever Given, the operation revenue in December 2020 reached NT \$24.58 billion that is about US $\$ 878$ million with a significant increase of 58.8 per cent over the same period in 2019.In addition, according to the performance of 2020 released by Kuehne + Nagel, the largest forwarder company in the world, in March 2021, Kuehne + Nagel realized Earnings Before Interest, Taxes, Depreciation and Amortization (EBITDA) of CHF F1.92 billion that is about US $\$ 2.098$ billion with a year-on-year increase of 5 percent.

Table 1. Performance of Major Liner Companies in 2020

\begin{tabular}{|c|c|c|c|}
\hline Liner company & $\begin{array}{c}\text { 2020Annual operating revenue } \\
\text { (USD 100 million) }\end{array}$ & $\begin{array}{c}\text { 2019Annual operating revenue } \\
\text { (USD 100 million) }\end{array}$ & $\begin{array}{c}\text { Year on year } \\
\text { growth (\%) }\end{array}$ \\
\hline Maersk & 397.4 & 388.9 & 2.2 \\
\hline Dafei ship & 314.5 & 303.0 & 3.9 \\
\hline $\begin{array}{c}\text { COSCO sea } \\
\text { control }\end{array}$ & 262.5 & 231.5 & 13.4 \\
\hline Herbert Roth & 145.8 & 141.1 & 3.3 \\
\hline EVA shipping & 72.4 & 66.6 & 8.7 \\
\hline $\begin{array}{c}\text { Yangming } \\
\text { shipping }\end{array}$ & 51.1 & 49.3 & 1.76 \\
\hline HMM & 57.6 & 49.6 & 16.1 \\
\hline
\end{tabular}

Based on the record performance in 2020, the common practice of shipping companies in 2021 is not to actively sign long-term agreement contracts with shippers as usual. Normally, it is time for the capable shippers and the shipping companies to sign the long-term agreement contracts for the coming year in April to May every year, however, shipping companies is abnormal in signing the long-term agreement contract this year. Some even cancel it and implement the market price totally. This is enough to show that the freight rate has great volatility, instability and uncertainty. However, in the case of absence of long-term agreement contract as insurance in some sense, once the global supply chain returns to normal operation the shipping demand will return to a similar level before the pandemic as well. Because the pandemic is not the driving force for the long-term growth of the global economy. Under the current situation, shipping companies should reasonably or rationally view and treat the high operation revenue in 2020 or even 2021 and make early arrangements for future operation.

\subsection{Response of Trade and Production Enterprises}

\subsubsection{Perform Supply Chain Interruption Management}

The pandemic situation has just improved when such firms see the hope that they could export they encounter such international shipping problems which may make firms that have not easily survived from pandemic face the dilemma of being unable to continue to operate again. This is enough to attract the attention of many trade and production enterprises that have not considered supply chain interruption management before. From the perspective of economics, it is impossible to arrange preventive measures for every one of the variety risk types to deal with the interruption of shipping supply chain caused by such endless small probability events. When it is difficult to prevent in advance it should focus on the post disposal link. The most common and effective means of post disposal should be the full application of insurance but this means cannot be implemented after the event. The enterprises need to insure according to the prediction of their own shipping supply chain risk. For example, the Trade Disruption Insurance in London insurance market aims to protect enterprises from financial losses caused by embargo, confiscation of cargoes, terrorism, strike, political violence or war, as well as protect companies from pure economic losses caused by insured risks such as ship failure, port closure, passage blockage and natural disasters. 


\subsubsection{Against Booking Cancel by Shipping Company}

Because of the huge demand gap, shippers seek shipping space in the market like an "auction", that is, the higher the price the shippers who have obtained the shipping space. However, it cannot be guaranteed that the shipping company will not take back the promised shipping space and resell it because of the high price of competitors. Phan Minh Thong, CEO of Phuc Sinh, one of largest pepper and coffee export companies in Vietnam, said that the container transport cost had increased by 700 per cent but many of his orders had not been delivered because "they had been unilaterally cancelled by the shipping company". "We reached an agreement with the shipping company at night but we were told to cancel in the morning because they received a higher offer. Sometimes we receive cancellation notices for 40 to 50 containers." He said so. If, on the contrary, the shipper cancelled the spaces after booking or may charge so called dead freight and other related fees and losses. In the face of this situation, the shipper should actively seek remedies to protect its rights and consult the lawyers specializing in maritime law and maritime business.

\subsubsection{Prevent the Risk of Seizure of Bill of Lading}

At present, the freight rate in the shipping market fluctuates greatly and frequently, so enterprises or freight forwarders may face the situation that shipping companies require to increase the freight rate after the goods are shipped because the freight rate continues to rise. If there is a dispute over freight rates and other expenses under the bill of lading led to the shipping company detaining the issued original bill of lading, thus consignee may not be able to pick up the goods in time, then both the consignee and the shipper will face many additional losses. In view of this situation, the shipper should improve its awareness of prevention which in detail is keeping and retaining involved documents including not only booking for spaces, communicating emails and expense invoices. Compared with the losses caused by the withholding of orders, these works should be the most economical way for the enterprise to protect itself. Only when these documents are complete, once the bill of lading is seized, the enterprise seek help from the court or take legal action that will be more conducive to safeguard its own rights and interests or favorable to reach an agreement through consultation.

\subsubsection{Solve Transportation Problems with Transportation Solutions}

Enterprises should consider using multiple modes of transportation on the premise that the cost is affordable and controllable. For example, sea-rail intermodal transport and other multimodal transport can divert export goods. For example, China-Europe freight trains is an alternative shipping solution. COSCO Shipping also gives full play to advantages of comprehensive transportation by means of "road to water", "road to rail", "rail to water" and "air to water", so as to break through the blocking points of the supply chain to ensure the smooth flow of the global supply chain.

At present, freight forwarder companies have chartered ships to operate container liner routes and even goods owners charter ships in long-term to transport their own goods. Home Depot is the largest home building materials chain supermarket in the world, ranking among the top three North American consignees with 520 thousand TEU shipping volume in 2020.The company will start operating its own ship to transport 100 per cent of its own goods in July 2021.This is an extreme method that is not suitable for common enterprises to deal with the current situation of high price fluctuation and high uncertainty in the shipping market for a long time what aim at ensure the normal operation of their own supply chain. The impact on how the shipping market develops in the future is unknown, Home Depot is a pioneer then Wal-Mart, Amazon and other giants whether choose to keep up will have a virtual influence to international shipping market.

\section{Conclusion}

The rethink profoundly brought by the pandemic to the world is to arouse the worldwide attention to the security of shipping supply chain, especially under the background of global economic integration, the probability of forced interruption of supply chain is increasing and following negative 
impact more and more strong. In the post-pandemic era, the whole world is facing the problem of supply chain interruption. The interruption of the global shipping supply chain is reflected in the continuous sharp rise of prices of international shipment represented by container transportation. The causes of price rise are multi-dimensional, so the response measures should not be single from the national level, industry and enterprise level. In addition to its own management system, the supply chain should also pay attention to the risk control effect of business interruption insurance, so as to realize the comprehensive management of the interruption risk of shipping supply chain. On the basis of price adjustment by market forces, the government or relevant departments need to intervene and macro-control with invisible hands and give full play to the economic functions of the government to support the recovery of world economy, global trade imbalance and global supply chain interruption by means of policy instruction. The problem of global shipping supply chain interruption needs to be solved jointly by all parties, strengthen pandemic control and solve the problem from the source so as to release the delayed transportation efficiency as soon as possible and to provide guarantee for the normal operation of international trade. In addition, we should strengthen the supervision of the market and crack down on any possible violations of the rules to protect the interests of all participants in the market.

The explosive demand release triggered by the pandemic tests the global supply chain system which needs to attract the attention of the world and jointly find the best solution. However, the event this time can be said to be a small probability event. Therefore, the change or derivative impact by this time pandemic on the future is a problem that needs to be discussed and studied in the next step. For example, the explosion of the issue this time is shortage of containers. In order to solve this problem, in the case of oversupply of transport capacity and idle containers in previous years, it is worth careful thinking whether these more produced containers will be idle in the future and break the supply-demand balance of the global container market. Peter Sand, chief shipping analyst of BIMCO, believes that in the long run the industry will have to face the problem of excess capacity in the pre-pandemic market. This concern also includes newly delivered vessels. The report published by Clarksons suggested that in the first six months of 2021, ship transactions exceeded 85 million dead weight tonnage with an increase of 131 per cent over the same period last year and 31 per cent over the second half of last year and more than twice the long-term trend. Among them, Chinese and Greek shipowners are to some extent the most active ship buyers so far this year. The analysis warned that steel prices and currency movements may make it more difficult for shipyards to obtain similar orders in the second half of the year. In view of this, China should not only actively deal with the interruption of the global shipping supply chain, but also look at the problem from the perspective of long-term development and formulate response plans and measures with the idea of sustainability.

We should focus our mind on the future, not the past." We live in a fast-changing world, and the global economy is undergoing more profound changes. We must therefore closely follow the trend of the global economy, identify its underlying dynamics, keep to the right direction, and, on that basis, take bold action.

\section{References}

[1] Chinese President Xi Jinping address titled "Seizing the Opportunity of a Global Economy in Transition and Accelerating Development of the Asia-Pacific" at the Asia-Pacific Economic Cooperation (APEC) CEO Summit at November 10, 2017.

[2] Youchao Chen, Dequan Zhou. Analysis and forecast of China's shipping boom (the fourth quarter of 2020). Shipping Management, Vol.43(2021) No.02, p.33-35.

[3] Information on: Clarksons: https://www.cnss.com.cn/html/hyrd/20210707/341823.html.

[4] Information on: https://www.forbes.com/sites/forbesbusinessdevelopmentcouncil/2021/05/25/how-theshipping-container-crisis-demonstrates-the-risk-of-imbalance-in-global-trade/ $\mathrm{utm}$ - campaign $=$ Social $\%$ 20Member\%20Articles\&utm_content $=168150788 \& u t m \_m e d i u m=$ social\&utm_source=twitter\&hss_cha nnel $=$ tw- $845063280955707394 \& \mathrm{sh}=74 \mathrm{ca} 11221090$. 
[5] Information on: https://www.worldshipping.org/news/normalized-demand-not-regulation-will-solvesupply-chain-delays.

[6] Information on: China Shipowners' Association. http://www.csoa.cn/doc/19856.jsp.

[7] Information on: General Administration of Customs, P. R. China, http:// www. customs. gov. cn/ customs/ 302249/zfxxgk/2799825/302274/302275/3761870/index.html. 